\title{
Social Engineering Approach to Manage Social Environmental Dispute Impacted by Development Plan (Case Study of Floating Storage Regasification Unit/FSRU Development Plan)
}

\author{
Endang Susilowati $^{1}$, Zaenal Arifin ${ }^{2}$, Sukriyah Kustanti Moerad ${ }^{3}$ \\ Department of Development Studies - FBMT, Institute Technology of Sepuluh Nopember Surabaya \\ endangits18@gmail.com ${ }^{1}$, antinmoerad01@gmail.com ${ }^{3}$ \\ Department of Physics-FIA, Institute Technology of Sepuluh Nopember-Surabaya, zaenal18@gmail.com²
}

Diterima: $12 / 07 / 2019$

Direview: $25 / 07 / 2019$

Diterbitkan: 30/12/2019

Hak Cipta @ 2019 oleh Penulis (dkk) dan Jurnal Sosial Humaniora (JSH)

*This work is licensed under the Creative

Commons Attribution International License (CC BY 4.0).

http://creativecommons.org/licenses/by/4.0/

\section{Subject Area: Social and Politics (Sosial dan Politik)}

Abstract [in ENGLISH]

One of the strategic issues in the 2016-2030 SDGs (Sustainable Development Goals), the 7 th (seven) goal is clean and affordable energy. The social engineering approach in the social-environmental dispute management of the affected community is an applied research from the case study of the Pasuruan FSRU development plan, namely building floating LNG storage and supporting facilities and facilities at sea, subsea pipeline construction located in the Madura Strait, in the north of the Regency Pasuruan and Sidoarjo Regency, as well as deploying land pipes in Permisan Village, Tambak Kalisogo, and Kupang, Jabon District-Sidoarjo Regency. This research is a descriptive analysis study, which is carried out with cross-sectional, in the study area. The data used in this study are primary and secondary. The primary data from participants in socialization activities of development plan were 33 respondents in Sidoarjo Regency and as many as 25 fishers respondents in Pasuruan City and Regency. Besides, the primary data from the questionnaire to 101 residents affected by land pipeline deployments and 29 people, fishing communities, joined in the HNSI in Pasuruan Regency and City. Often the development plans are hampered by the implementation, including strategic development plans, such as deploying fuel/oil and gas pipes, refineries, FSRUs, etc. due to the issue of dispute in the social environment. This study aims to support ongoing development activities, to underpin decisionmaking policies. The results of the study show that the community perception factor is very significant towards the development plan that must be managed. Management of these problems is a social engineering approach at the planning stage in the development process by involving various stakeholders ranging from the central government, local government, related agencies, NGOs, local figures, and communities affected by the development.

Keywords: - Floating Storage Regasification Unit (FRSU); Social Environment Dispute; Social Engineering Approach

\section{Background}

Energy security is one of the strategic issues in Indonesia, besides the issue of water resources and food security. This issue is also implied in National Development Goals (SDGs) for 2016-2030, which are listed in the seventh goal (7), namely clean and affordable energy. At present, the population in Indonesia is the fourth largest in the world, reaching more than 240 million people. This, of course, has a very significant impact on energy needs in the future. If this condition is not addressed wisely from the start, it does not rule out the 
possibility that serious problems will threaten the sustainability of development in various regions in Indonesia (Presidential Decree No.59 Year 2017 about National Development Goals (SDGs) for 2016 - 2030, n.d.).

One of the clean energy sources in Indonesia that has an important role is natural gas, with natural gas potential in 2015 reaching 150 TSCF (Trillion Standard Cubic Feet). The amount includes proven reserves of 102 TSCF and potential reserves of 46 TSCF. Mostly, the gas resources are outside Java, namely in Sumatra including Natuna with reserves of almost 56\%, Papua 16\%, Kalimantan 11\%, Maluku 10\%, Java 8\%, and Sulawesi $2 \%$. In 2015 production is estimated to be associated with non-associated and non-associated gas at 3.17 TSCF per year. If the gas potential is divided by output, Indonesia has reserved for the next 30 years. Thus infrastructure is needed to process the gas potential, including the development of FSRU (Rahman, 2018).

The use of natural gas dominates operations in the industrial sector and power plants in Indonesia. In the future, it is expected that the commercial sector, such as hotels, restaurants, hospitals, and others, as well as households / domestic sectors, will also use gas. The Agency has projected it for the Assessment and Application of Technology (BPPT) for the period 2015-2035, that total natural gas consumption is estimated to grow by an average of $2.2 \%$ per year or up to $1.6 \%$ in 2035. In 2015 the use of natural gas increased from 1,448 BCF (Billion Cubic Feet) to 2,367 BCF in 2035. The use of natural gas is as follows: the industrial sector reaches $51 \%$, followed by electricity generation $33 \%$, then transportation sector $2 \%$, domestic / household and commercial, each by $1 \%$. Besides, BPPT also predicts the most significant growth of natural gas usage in the household sector with an average increase of $17.6 \%$ per year, followed by the transportation sector $13.4 \%$, commercial $3.9 \%, 2.8 \%$ electricity generation and industry $2,9 \%$. Thus the projections and predictions need to be followed up to realize expectations as one concrete step to realizing the use of gas in the domestic sector even though the total consumption is minimal compared to other sectors. It is expected that in the future, the use of energy will be clean and affordable, namely the use of natural gas in the household sector will increase, along with economic growth. One effort to follow up on the use of natural gas energy needs to be built floating storage infrastructure of LNG-Liquid Natural Gas and its supporting facilities which are designed with a 15 $\mathrm{km}$ long pipeline and $14 \mathrm{~km}$ of land pipelines with pipe pressures> 16 bar (Arifin, 2019).

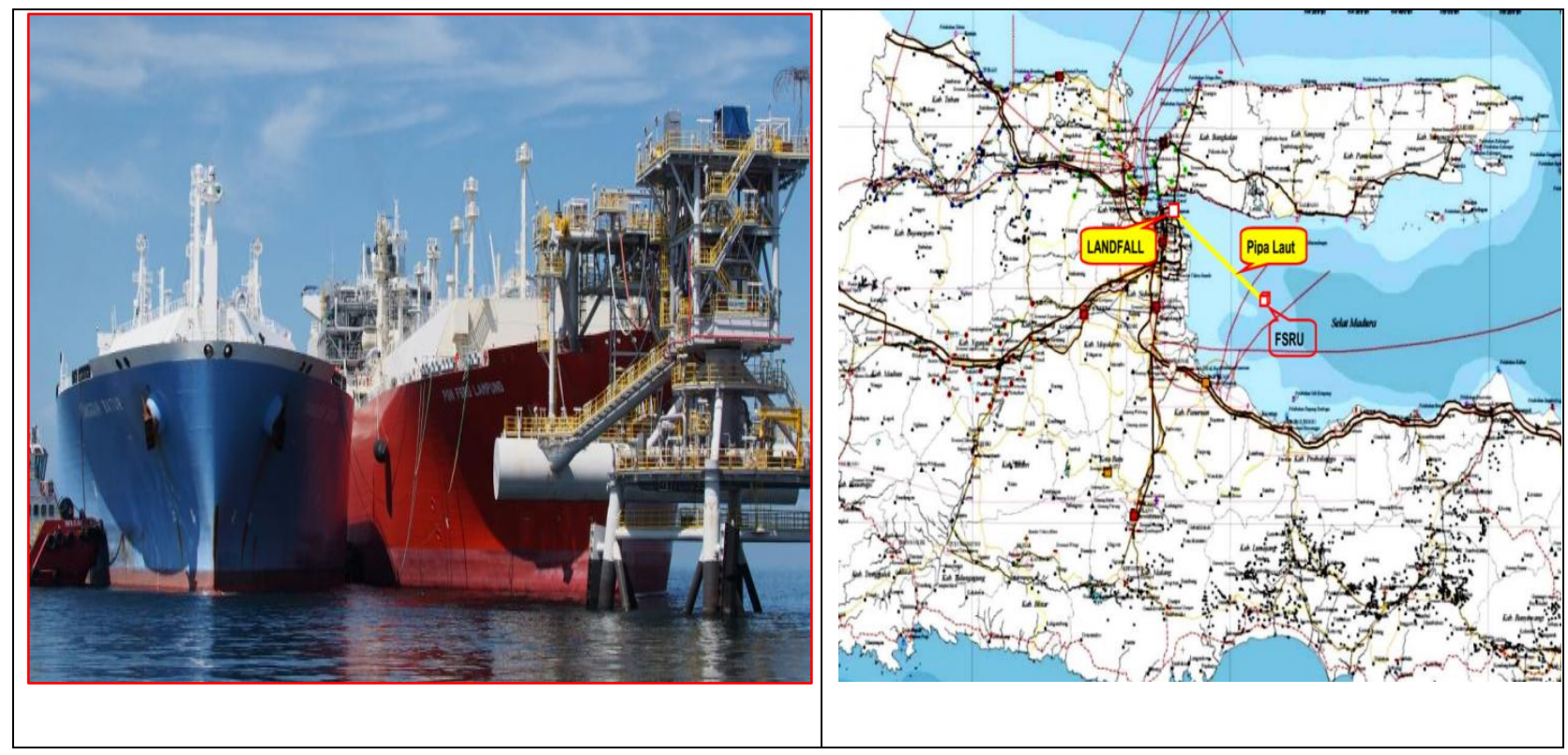

Figure 1. FSRU and Supporting Facilities and Overlay Map of FSRU Position and Subsea Pipeline 
The objectives of the planned development of floating LNG storage and supporting facilities are as follows: supporting government programs to increase gas energy use; increasing gas supply for industrial, household and PLN activities as a substitute for petroleum; and reducing environmental pollution specifically reducing the effects of greenhouse gases due to the use of fossil fuels. While the benefits of this development plan for the government are: the availability of LNG storage and regasification facilities; the existence of sources of LNG supply from within and outside the country; for the initiator of the activity is the fulfillment of LNG requirements for industries, households, and PLN, especially in East Java; while for the community is to increase the income of the population around the activities through the absorption of labor in the construction and operation stages. Although the development plan is very strategic and decisive and benefits the government, the initiator of the activity and the community, namely: supporting the government's plan, and increasing gas supply for industrial, household and electricity board (PLN) activities, and providing environmentally friendly energy, but in the process of obtaining permission, for example, environmental permits often cause problems with the community / social problems around the planned activities. Every effort to realize human welfare through development plans must be carried out by integrating environmental aspects, social aspects, and economic aspects into development strategies to ensure the integrity of the environment as well as the safety, capability, welfare and quality of life of present and future generations. The development will not only have a positive impact, but it can also have a negative impact in the form of environmental changes or pollution and even environmental damage. With the implementation of the principle of sustainable eco-development, the environmental impacts caused by development plans must be analyzed from the beginning of planning so that the steps to control negative impacts and the development of positive impacts through environmental management are not only for physical, chemical, and biological components but also for socio-economic and cultural or what is known as the $\mathrm{ABC}$ components (Abiotic, Biotic, and CultureSociety) can be prepared as early as possible (Susilowati, Moerad, \& Arifin, 2018).

Social environment disputes because the infrastructure development plan is a social problem that arises because of the infrastructure development plan. Development plans that require land acquisition for its implementation also often create disputes in affected communities (social, environmental dispute), for example, plans for constructing dams, highways/toll roads, electricity infrastructure, and deploying or trenching both gas and oil pipelines, and so on. The social-environmental dispute can cause failure in the implementation of development if it is not managed correctly according to culture and applicable regulations. The issue of social environment disputes will cause the permit to be hampered because it does not obtain the environmental feasibility from the technical and commission teams that evaluate environmental documents based on environmental feasibility criteria. In several cases, the development plan stated that the environmental feasibility criteria most often caused the implementation of development to be hampered because the issue of environmental permits was precisely not only a technical factor but a socio-cultural factor (Susilowati \& Windiani, 2018).

Furthermore, it was stated that every individual or group of people had different interests, and the differences in interests could lead to the emergence of conflict/dispute in the social environment. This condition occurs because of perceptions of perceived divergence of interest, or the belief that the aspirations 
of the parties to the conflict are not achieved simultaneously (G. Pruitt \& Z. Rubin, 2011). Thus it can be formulated appropriate environmental management so that environmental disputes can be avoided. The FSRU is planned to include a $14 \mathrm{~km}$ land pipeline stretching in 3 affected villages namely Permisan Village, Tambak Kalisogo Village, and Kupang Village and installation of offshore facilities in the form of Soft Yoke Mooring Tower (SYMT) permanently for FSRU mooring and pipe deployment along $15 \mathrm{~km}$ in the waters of the Pasuruan sea around the Madura strait that has the potential to disturb fishers who sail in the area. Deployment of pipelines on land through farmland and agricultural land. The land is usually used for various purposes of human activities, such as residence, agriculture, livestock, fisheries, infrastructure development and so on. Thus it can be concluded that land is a place with a particular administration that is used by humans for various activities for their survival. Land use activities are a physical form of community socio-economic activities. Land use is often based on soil type, location and certain economic factors (Erna, Sunsun, \& Dyah, 2011). Land-use change will cause several problems, namely the loss of livelihoods as rice farmers, pond farmers, loss of income from the production of rice fields or ponds, cause unemployment, and other social problems. In agricultural or fisheries business systems, land, ponds (land) are essential (commodity) production factors and have high economic value (Sahab \& Sugihen, 1977).

There is a possibility of land conversion in Permisan Village, Kalisogo Village, and Kupang Village, where land pipelines are planned for FSRU development, which causes social problems. The land function change in the form of ponds and horticultural agriculture in the region will be less and will decrease production. The land case consists of land issues and land disputes (Murad, 2019). Land issues are more technical in characteristic, the resolution is through technical instructions to implementing officials based on applicable policies and regulations, while land disputes are disputes that occur between two or more parties because they feel disturbed by the rights and control of the land, can be resolved through deliberation or court. A conflict will develop into a dispute if the party who feels disadvantaged expresses dissatisfaction. Therefore it can be concluded that disputes are a continuation of conflicts, or conflicts will turn into disputes if they cannot be resolved (Sembiring, 2016). Examples of cases in dealing with land dispute problems that occur in Sumatra between companies and local communities (Wahyono, 2005), carried out several efforts taken, as follows: 1). Land ownership must be settled legally or deliberation; 2) Persuasive approach from the government and investors, that ensuring the continuity of the company is very important to generate state revenue in order to support the development of various fields; 3) Open more extensive opportunities for the community to be involved in the company's operations; 4) Propose to decision-makers (government), to ensure security for the community and the company; 5) Make good communication between stakeholders related to the community so that there is no misunderstanding; 6). Improvement of the system that guarantees the justice of the parties; 7) Legal certainty regarding land ownership.

Some examples of social environment disputes that have occurred due to development activities: The case of environmental dispute near the location of the study was "The Case of Brantas Lapindo Mud in Sidoarjo Regency" (Saputra \& Muhammad, 2017) was a hot mudflow event concluded by the disaster because geologically there was mud volcano on the part drilled by PT Lapindo Brantas Inc, resulting in mudflow not stop being considered a natural disaster. The muddy inundation caused inundation of residential areas, rice 
fields, the industry in Reno Kenongo Village which caused losses not only for environmental aspects but also for economic and social aspects. This condition causes the community around the Lapindo Mud incident to become traumatized/have a negative perception of the development plan. (Susilowati et al., 2018) in the article "The Effect of Emic View on the Determination of Environmental Feasibility of the Java Bali Crossing Development Plan JBC - SUTET 500 k V Paiton - Antosari and SUTT 150 kV Antosari - Ship", from the aspect of community views (emic view), the planned development activities, some respondents stated that they disturbed specific social values, or emic view, religious leaders and Balinese Hindu organizations (Bhisama Parisadha Hindu Dharma Indonesia / PHDI), because the Crossing Tower Site is adjacent to the Temple Segara Rupek with a distance of $\pm 400 \mathrm{~m}$. Based on the Bhisama Parisadha Hindu Dharma Indonesia Regulations concerning Purity of Temple No. 11 / Kep / I / PHDI / 1994, states that these holy places have a radius of sanctity called Kekeran area, with the size of Apeneleng, Apenimpug, and Apenyengker. Segara Rupak Temple is included in the Pura Dhah Kahyangan category applied in Apeneleng Alit size at least $2 \mathrm{~km}$ from Pura. While the general public and in the business world are not socially disturbed for the reason: The power plants in Bali Province have not been able to meet the electricity needs on the island of Bali; Population growth from year to year increases so that the electricity needs from year to year continue to increase; The electricity flow is smooth and there is no blackout.

From this background, this study aims to anticipate the emergence of social environment disputes due to the development plan of Pasuruan FSRU and its supporting facilities. The problems in this study are formulated as follows: 1. Characteristics of socio-economic conditions of the population in the study area. 2. Negative impacts/perceptions that are likely to cause social-environmental disputes on development plans; 3 . The appropriate form of management to overcome the social environment disputes affected by development.

\section{Research Methods}

This research is a descriptive analysis study, carried out in a Cross-Sectional manner, with the study area of Permisan Village, Tambak Kalisogo Village, and Kupang Village-Jabon Sub-District, Sidoarjo Regency (the place for the deployment of land pipes); and Regency and City of Pasuruan, East Java Province (location of FSRU). The data used in this study are primary and secondary. Primary data from the dissemination of activity plans for related stakeholders and representatives of affected communities, with a total of 33 respondents in Sidoarjo Regency and 25 fishers in Pasuruan Regency and City; Primary data from questionnaires, participation and in-depth interviews (dept interview, grievance mechanism) with as many as 101 respondents of residents along land pipeline deployments and 29 people, fishing communities, who are members of the Indonesian Fishermen Association (HNSI) in Pasuruan Regency and City. While secondary data from relevant literature studies, journals, research results and secondary data from related institutions. The analysis used in this study is interpretive, causal, logical, descriptive and reflective critical analysis. This qualitative study was concluded after the fundamental propositions were obtained from the results of previous analyses. The following is a picture of the documentation of research activities. 


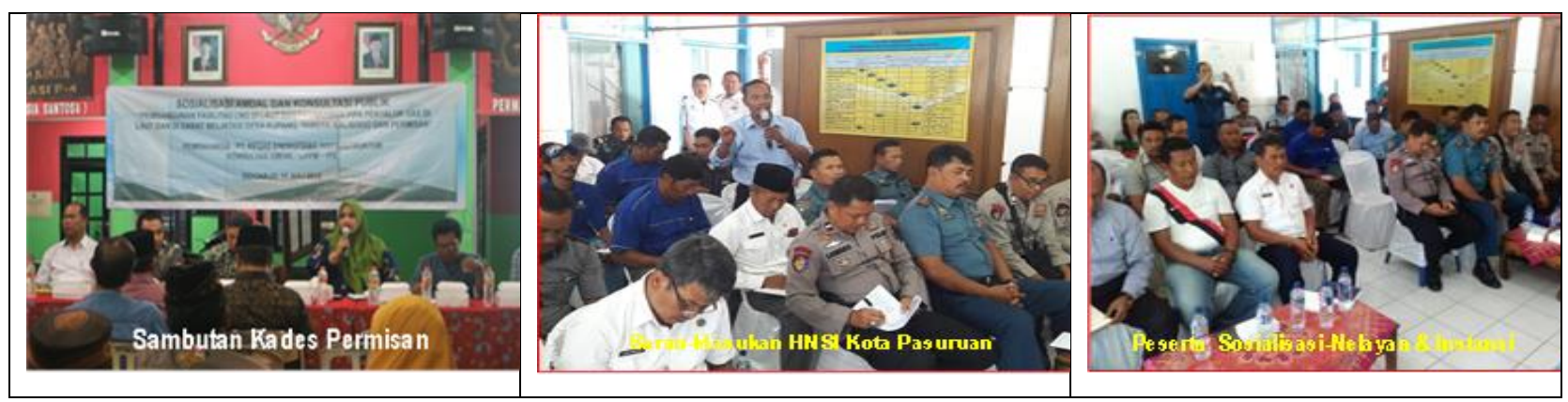

Figure 2. Socialization to the Community and Related Stakeholders (Social Engineering Approach)

\section{The Results of Research and Discussion}

The construction of the FSRU must also consider the economic, social, and cultural aspects of the community in an integrated manner and synergistically so that more optimal results can be achieved. Based on this approach, the various field findings in the research related to the FSRU development plan were used to analyze and identify the problems examined in the study, as follows.

\section{Characteristics of Population-Based on Socio-Cultural Conditions}

\section{a). Social Interaction in the Research Area}

Social interactions or social processes in the research area are associative processes or social processes that lead to the form of cooperation that is manifested in cooperation activities. Many religious values color the spirit of the community, including local culture, culture, customs, and habits. The community in the research area is quite homogeneous, both in terms of language, religion, culture, and customs, but quite some migrants from other regions to the area because of marriage and because of work as fishermen. The majority of the people are Javanese ethnic groups, and others are Madurese.

The life of the community includes the community type community, traditionally generally mechanically organized, which prioritizes the community rather than the rational community which is organically organized. So strong are religious values that Islamic values characterize almost all local traditions, cultures, and arts. The community tends to prioritize the spirit of togetherness to realize social harmony. Therefore, always trying to avoid destructive behaviors that are considered to lead to social disintegration. So that it always takes accommodative/deliberative ways and avoids the ways of conflict, conflict, no / rarely violence or antagonistic ways of solving any problems that arise. The typology of leadership that developed tended to the type of formal leadership such as the Village Head and his equipment, although he also respected and respected non-formal leadership such as religious figures. From the aspect of social life, the function of social institutions is important because it is a unifying tool; it can also be used as a tool for monitoring and protecting the community. Social organizations in the study area that were participated in by some communities, among others: LKMD, Karang Taruna, Wisma Dasa / PKK Group, Recitation / Arisan Group, Fisherman Farmers Group, etc. The Combined Farmers Group (Gapoktan) in the study area included: Permisan Village is a 46-member Tani Makmur, in the Tambak Kalisogo Village named Gapoktan Sumber Rejeki consisting of 35 people, while in Kupang Village is Gapoktan Kutama with 209 members. 
If seen from the pattern of relations between residents living in the study area, the results of the interviews show that all respondents $(100 \%)$ stated that the pattern of relations between citizens was excellent and harmonious. From this excellent and harmonious relationship, it is also supported by the frequency of joint meetings between residents both when there are community celebrations, recitations, community meetings and social gatherings. The distribution of types of meeting frequency will be explained in the following figure.

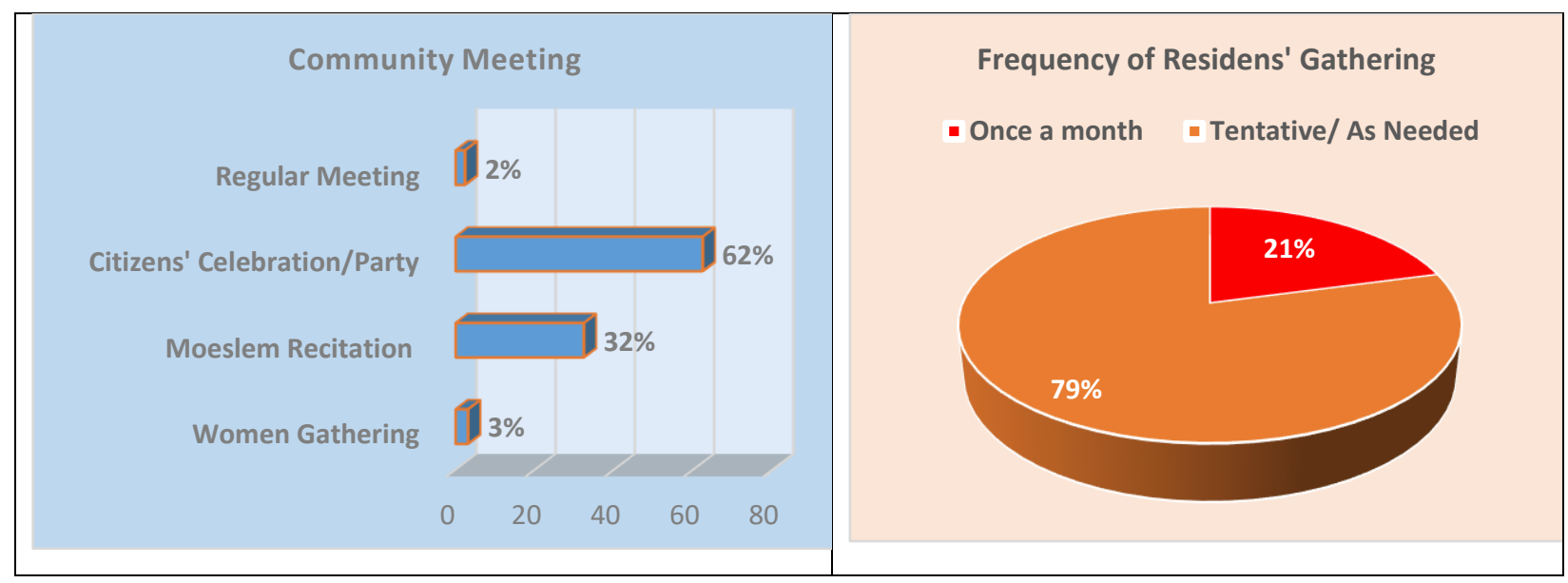

Source: Primary Data, the Year 2019

Figure 3. Moments of Residents' Gathering in Study Area

It was concluded that the social interaction in the study area was quite strong and functional, the majority of respondents stated that the gathering moment was declared Citizen Celebration as many as $63.00 \%$ of respondents; Recitation was stated as $32.00 \%$ of respondents and as many as $3.00 \%$ of respondents stated when there was social gathering, and when there are regular village meetings started at $2.00 \%$ of respondents. Then the other gathering moments of the community are Keep the Village. The frequency of gathering activities is classified into frequencies: once every two weeks, every month, and others / tentatively. Most of the respondents $79 \%$ answered the uncertain/tentative frequency as needed. As many as $21 \%$ of respondents gather once a month because arisan or religious / yasinan activities are usually held once a month.

\section{b). Social Life and Security(KAMTIBMAS) in the Research Area}

In social life, sometimes, problems/conflicts are encountered between citizens. According to the majority of respondents, the conflict was resolved by deliberation led by community leaders (RT / RW / Village Head); besides that, it was also resolved on its own in a family manner. This depends on the size of the problem. The distribution of conflict resolution among selected citizens is presented in the following figure. 


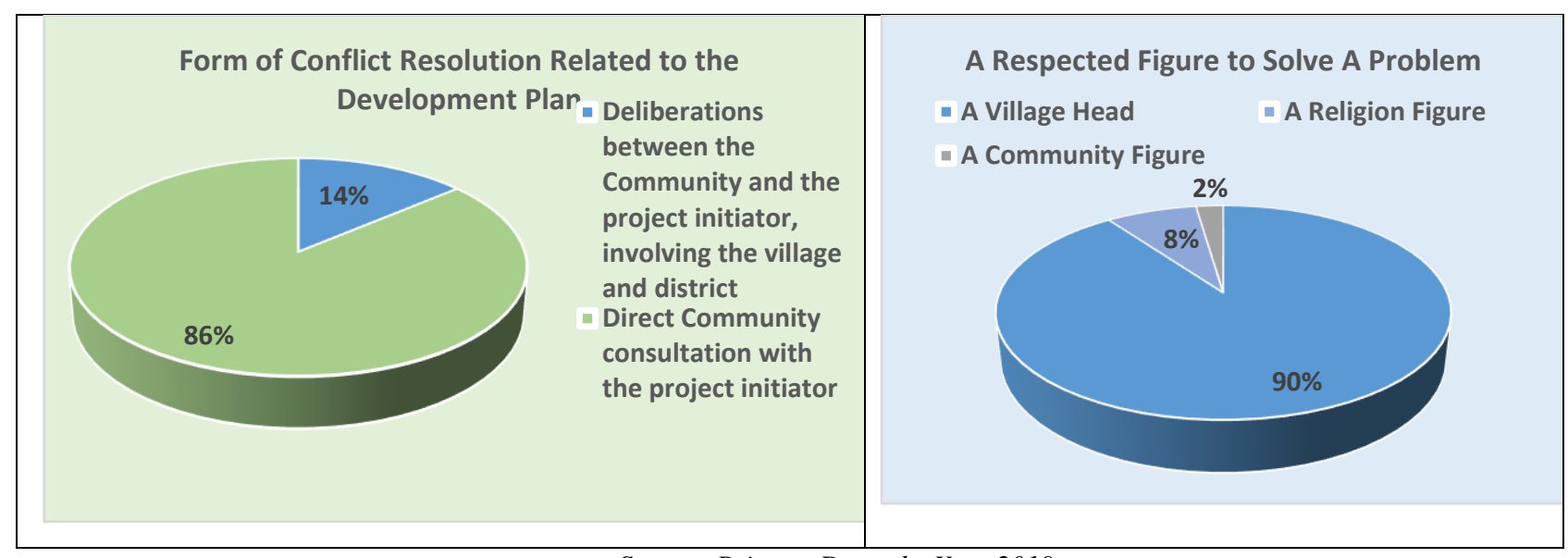

Source: Primary Data, the Year 2019

Figure 4. Form of Conflict Resolution and Respected Leader

From the results of the study concluded, as many as $15 \%$ of respondents resolved the conflict by resolving themselves, but in general, $85 \%$ of respondents preferred to solve the problem by way of deliberation led by community leaders.

Social life is a benchmark that can be used to analyze the state of the social environment, relations between citizens, frequency of meetings, and patterns of life of people in the region. KAMTIBMAS is an essential thing in living a social life because everyone needs the level of security, order and comfort. Based on the results of research in three villages, namely Permisan Village, Tambak Kalisogo Village, and Kupang Village, it can be seen that all 101 respondents $(100 \%)$ said that the conditions in the respondent's living environment were relatively calm and harmonious. Every social environment has someone who is respected / consideration to resolve problems that arise in the community, including village heads, community leaders and religious leaders. From the picture, it appears that the figure respected by the respondents was the village head, stated as many as $90.00 \%$ of respondents. While other respondents, $8,00 \%$ answered religious leaders and as much as 2,00\% answered community leaders. By knowing the figures that are respected by the community, the initiator of the activity plan must always coordinate not only with the relevant stakeholders but also must coordinate with the village head, religious leaders, and community leaders in the study area.

In connection with the planned development of floating LNG storage and other supporting facilities, if there is a problem/conflict with the affected community. It was concluded, the form of settlement related to the construction of floating LNG storage and other supporting facilities, the most desired by respondents (86\%) was family consultations between the community and the initiator peacefully to reach consensus and involve the village or sub-district government, and as many as $14 \%$ of respondents wanted direct deliberation with the initiator.

\section{2). Community Perception of the FSRU Development Plan}

Community perceptions of the development plan are an essential part of the development plan because it is related to the community's response to the plan. The response of the community can be positive or negative, and the response from the community will affect the smoothness or obstacles of a project/development plan. 
Before the construction activities were carried out, socialization of the development plan was first carried out to community leaders and related stakeholders, while not all of the affected communities had participated in the socialization. Therefore, after conducting interviews related to the planned activities, a small number of affected communities had heard of plans to build floating LNG storage and supporting facilities, namely 12 respondents $(12.00 \%)$. While 89 respondents $(88.00 \%)$ said, they had not heard. People who have been aware of the planned development of floating LNG storage and Pasuruan FSRU facilities from various sources of information ranging from formal socialization/meetings conducted previously by village officials, fellow citizens, and by project proponents, as well as announcements of banners in villages and sub-districts.
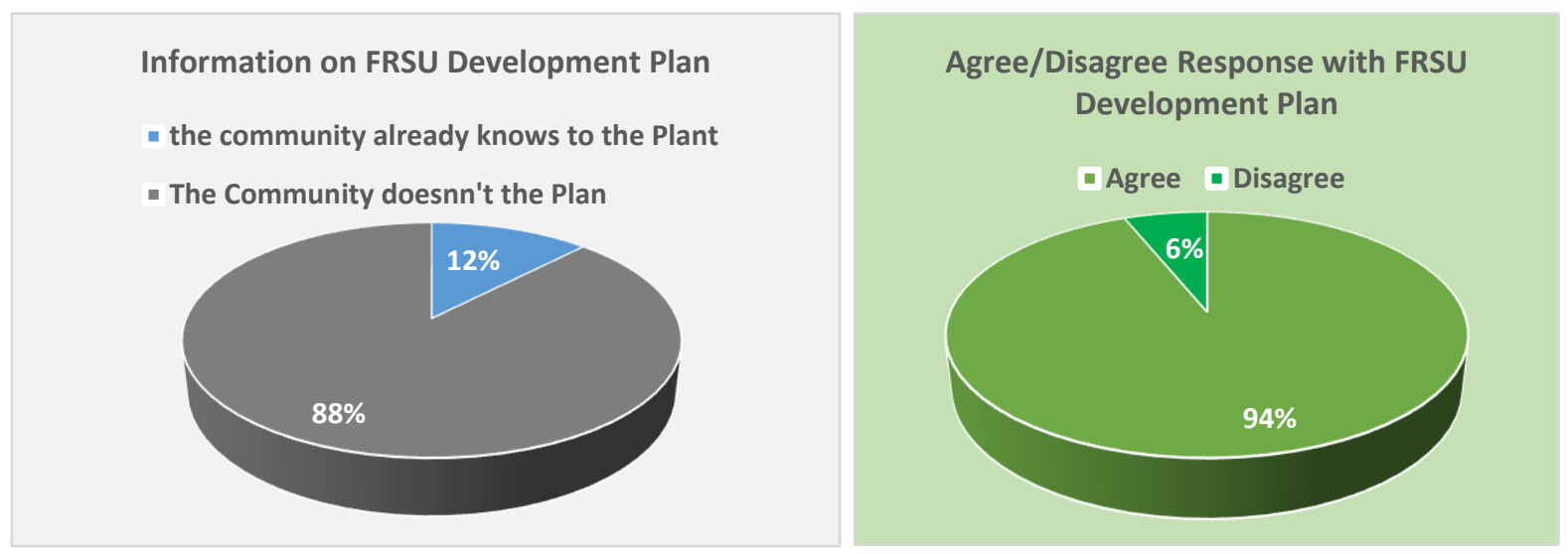

Source: Primary Data, the Year 2019

Figure 5. Information and Perception of Respondents Against the Development Plan

However, after being explained when the interview took place, related to whether or not the community agreed to the project development plan, 95 respondents (94.06\%) agreed and six respondents (5.94\%) said they did not agree to the construction of floating LNG storage and supporting facilities. The distribution of reasons for respondents agree then will be presented in the picture as follows.
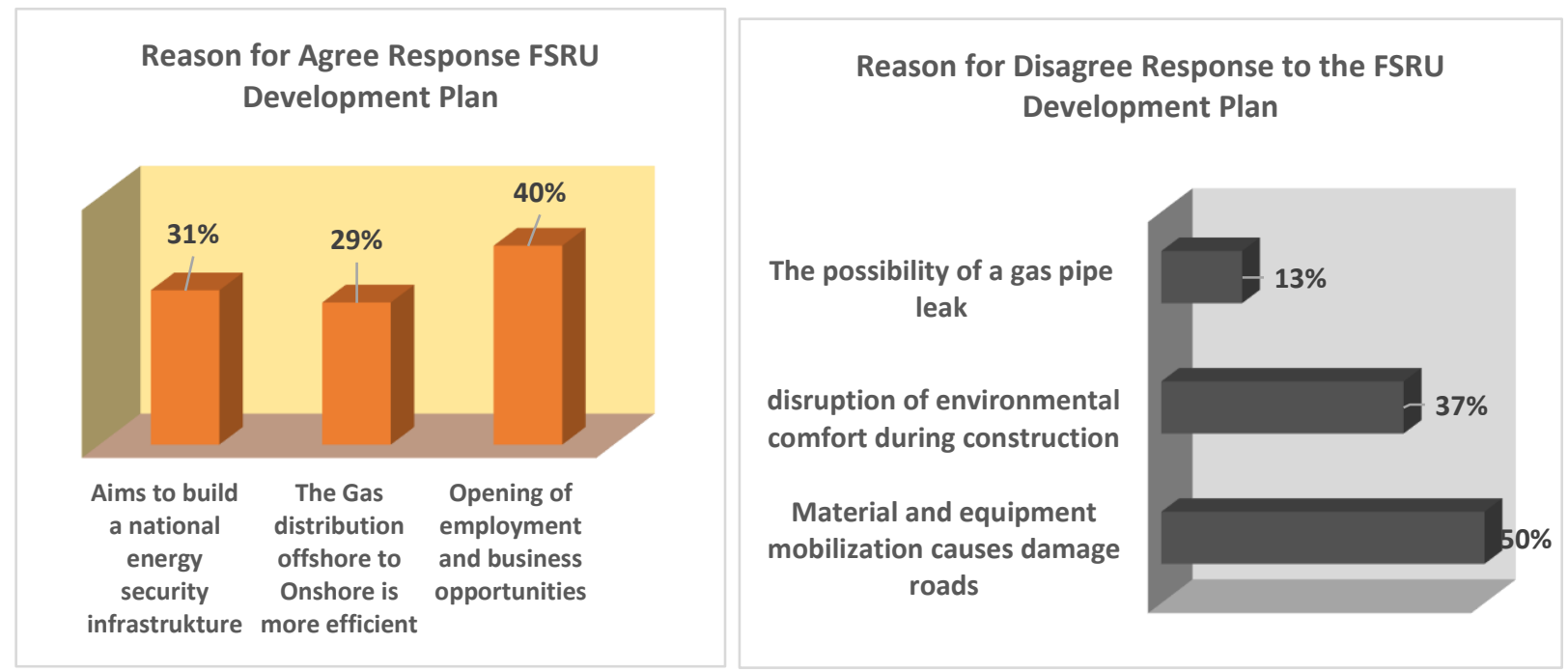
Source: Primary Data, the Year 2019

Figure 6. Reasons Respondents Agree, but There Is Still Worry with The Plan

It was interpreted that the reason the respondents agreed was that the option of building infrastructure for national energy security was stated by $31.00 \%$ of respondents, and the option of opening employment and business during construction and operation was stated by $40.00 \%$ of respondents. Then the option of efficient gas distribution from Pasuruan FSRU is $29.00 \%$ of respondents.

Furthermore, with the planned development of this floating LNG storage, although the majority of respondents agreed, there were still various concerns. As already stated that 95 respondents agreed and firmly expected the construction of floating LNG storage and other supporting facilities so that national energy needs were met. However, there are concerns, as shown in the picture above, namely the respondents' concerns that there will be road damage during material and equipment mobilization as much as $50 \%$ of respondents. Then the concern about environmental comfort disturbances during construction is $33 \%$, and $17 \%$ of respondents are concerned about the existence of gas pipeline leaks, there must be a precise emergency response mechanism in the event of a pipe leak.

\section{a). Community Attitudes towards the Development Plan}

Regarding the planned development activities, the attitude of the community agreed, because this activity would overcome the problem of the need for energy that must be met. In addition to these reasons, this development plan inspired/envisioned the respondents' wish to open/run businesses around the development area. As many as $77.00 \%$ of respondents or 78 people have the desire/interest to open/run a business, while $23.00 \%$ of respondents or 23 people are not interested. The type of business that is wanted to be run by 78 respondents who are interested in opening a trading business and providing food businesses for workers.

The reason for the respondents not agreeing was that two people (1.98\%) stated that they were worried that there would be the eviction of their homes, and as many as four people (3.96\%) stated that the vehicle transporting the project material would cause road damage and air pollution in the environment.

With the planned development of floating LNG storage and other supporting facilities, expectations, and suggestions from the community are needed to evaluate, manage impacts, support and support development plans. The big expectation from the community regarding the construction of floating LNG storage and other supporting facilities is that when construction will begin, there must be socialization/notification to affected communities, attention to the safety of workers and the community, and the surrounding environment because the planned area of activities will be crowded and activity intensive. Suggestions from the public regarding the construction of floating LNG storage and other supporting facilities include the following.

- Conduct socialization or notify the community, especially the people who live around the pipe deployment area if construction activities will begin

- Maintain the security and safety of workers and the surrounding community.

- The workforce is prioritized from the surrounding community so that besides opening employment opportunities, it can also improve the economy of the community.

- Maintain environmental security (KAMTIBMAS) during construction. 


\section{b). Attitudes and Perceptions of the Village Head of the Affected Area}

From the results of interviews and the distribution of questionnaires with the village head affected by the LNG pipeline deployment project, it is expected that there will not be a significant negative impact on the environment. Communication carried out to socialize the community regarding the addition of LNG pipelines in Kupang Village, Kali Sogo, and Permisan Ponds must be intense if construction will begin. Because it is predicted that there are things to complain about, including the existence of social jealousy of labor and also concerns about pipe leaks, as well as compensation for affected assets through the deployment of land pipelines.

\section{Survey Results on the Sea Side (Fishermen from Pasuruan Regency and City)}

Fishers affected by the FSRU development plan and deployment of subsea pipelines are fishermen operating around the FSRU construction site and deployment of the pipeline at sea. Generally, fishers are looking for fish with small outboard motorboats and mini purse in 5 GT - 25 GT, barges, also there are still fishermen who use trawlers that are not environmentally friendly (according to Fisheries Law No. \& 2016 and Regulations Minister of Maritime Affairs and Fisheries No.1 of 2017).

\section{a). Perception of Affected Communities in Pasuruan City}

Perceptions of affected communities in Pasuruan City on the planned development of the Gas Pipeline Network and the Floating Storage Regasification Unit (FSRU) of Pasuruan were measured through socialization activities for the involvement of fishing communities, fishermen groups, Indonesian Fishermen Association (HNSI Pasuruan City and Regency) and interviews with respondents selected. The results of the community perception analysis during the socialization of 25 respondents related to the development plan are described as follows:

\section{- Community Perception When Socializing the Plan of Activities}

All respondents $100.00 \%$ ( 25 people) of socialization activities agreed on the FSRU development plan and gas pipeline installation, but there were still socialization participants who were worried at the development stage, which included: the pre-construction stage, the construction phase, and the operation stage. In the Pre-Construction phase, there were 14 respondents (36.00\%) who were worried. Of the 14 respondents, the highest perceived type of concern (64.29\%) was about damage to the marine environment, and shipping paths not normalized could cause a decrease in fish catches and high operational costs because fishing became farther than before project/development activities, which will affect income. More types of other concerns, as shown in the following picture. 

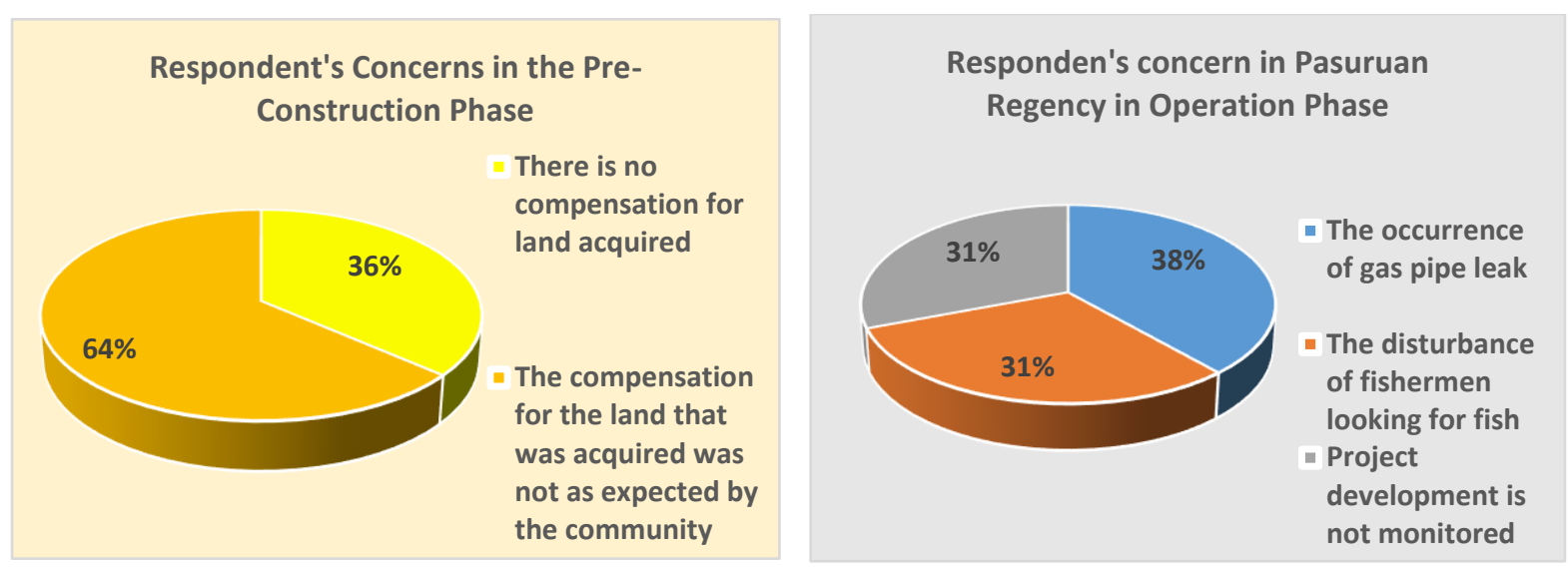

Source: Primary Data, the Year 2019

Figure 7. Respondents' Concerns at the Pre-Construction and Operation Stage

While in the construction phase, there were 12 respondents (48.00\%) who were worried. These concerns include KAMTIBMAS disturbances, such as demonstrations by fishers because their fishing routes will be disrupted, stated $33.33 \%$ of respondents; then, as much as $66.67 \%$ worried about sea pollution caused by construction waste.

Next to the operation phase, there were 13 respondents $(52.00 \%)$ who were worried, among others: the occurrence of pipe leakage was stated as much as $38.46 \%$ of respondents; disruption of the activities of fishers looking for fish because of the existence of floating LNG storage facilities and subsea pipelines stated as many as $30.77 \%$ of respondents; The construction is not monitored so that the quality of development is not optimal, there are fears of polluting the surrounding waters which can cause fish populations in these waters to decline, stated as many as $30.77 \%$ of respondents.

\section{- Perception of Fishermen Community Results of Interviews with Respondents}

The current conditions (existing) of activities carried out by other parties, which interfere with fishermen's fishing activities are: Catching fish using Trowel, fish bombs, waste contamination into the surrounding plant, oil drilling business, basing large vessels, dredging and installing pipes at sea. From the results of interviews with selected respondents from Lekok Subdistrict, Pasuruan Regency as many as 12 respondents (80\%) out of a total of 15 respondents stated that the operation of the Pasuruan FSRU would affect the productivity of instincts; Likewise, as many as 5 respondents (35.71\%) out of a total of 14 respondents in Punggungrejo Village stated that these activities would affect the productivity of fishermen. With the existence of these development activities, the operations of fishermen have increased because the sea lane has become so far that the fuel needs for their boats have increased; sea pollution will occur due to construction activities from material remains; and there are fears of deploying pipes at sea causing pollution so that fishermen's catches will decrease because fish move. Data on fishermen's perceptions of the development plan for the Pasuruan FSRU are fully displayed in the following figure. 


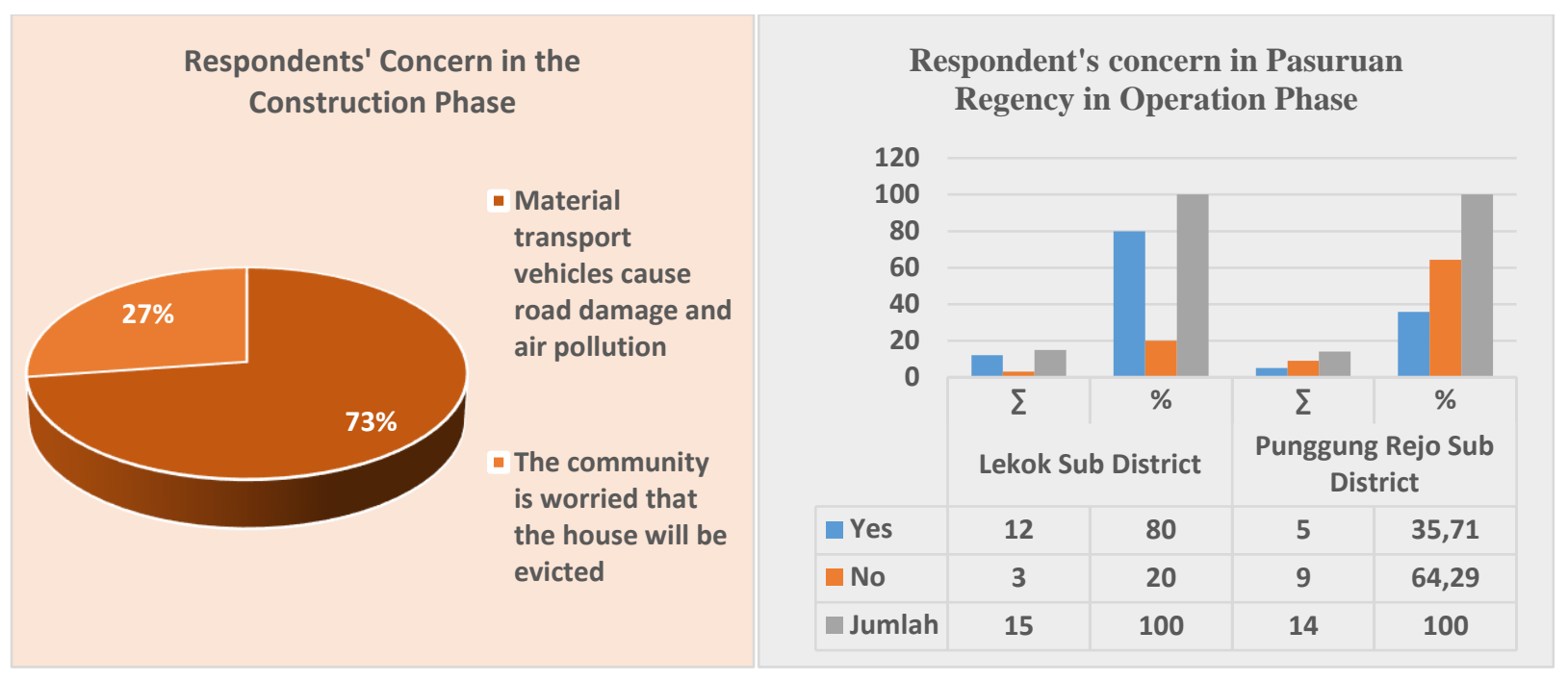

Source: Primary Data, the Year 2019

Figure 8. Respondent's Perception of Pasuruan FSRU and Fisherman Productivity

\section{Management of negative impacts/perceptions that arise}

The social impacts that are expected to arise from the planned deployment of land and sea pipes are negative perceptions of the community due to the acquisition of land/assets during pre-construction; the impact of environmental pollution during construction; as well as the impact of land pipeline leaks and fisherman disturbances at sea, etc., the impacts that arise must be managed with an institutional approach, and a social approach (social engineering) as well as a technology approach to minimize negative impacts and optimize positive impacts. The summary of opinion suggestions and responses from community leaders on the FSRU development plan are as follows:

- Mr. Mochamad (Kupang Village Head): If the pipe to be planted/installed across the Kupang Village area, separate information must be carried out in Kupang Village

- Mr. M. Thohari P (Permisan Village NGO): There must be an explanation of the equipment used for pipe installation and convey the activity/installation schedule to the residents. Before the construction activities begin, the residents whose homes are passed by the pipeline must have the right solution so that a good relationship is established between the initiator and the community.

- Head Village Tambak Kalisogo: If the pipe installation activities cross people's activities (stalls, shops, houses, etc.) so that compensation is clarified. Please pay attention to village infrastructure such as roads and others for Tambakkalisogo village south of the river because the southern part of the river cannot develop, in contrast to the north of the river the attention of the Sidoarjo Regency government is because there are Industrial Estates

- Mr. Siswanto (BPD Kalisogo Village): During the operation of the gas pipeline, it is essential to pay attention to the maintenance and supervision of the pipeline so that environmental safety can be optimized.

- Mr.Mukhlis BPD (Kupang Village): Deliberation is held concerning the livelihood fields of the people to be crossed by the pipeline, the workforce to be recruited during the construction and operation phases, and emergency responses to the occurrence of the gas pipeline installation. 


\section{Conclusion}

The results of the study indicate that the characteristics of the socio-cultural conditions of the people in the planned development area are relatively good. Therefore do not let the right conditions occur in the social environment dispute because of the development plan.

One of the consistent approaches applied in development that has the potential to cause disputes in the social environment of affected communities or intersect with interests with other institutions, including the interests of the central government and local governments, is a social engineering approach. The social engineering approach must be community-based by adhering to the following principles:

- Community aspirations, social engineering approaches based on the needs, ideas, and desires of the people discussed and accommodated the most rational and acceptable voices of the people.

- The interests of the community, the social engineering approach prioritizes the fulfillment of shared needs above other interests, to benefit the community.

- Community capacity, this approach considers the level of community capacity as the basis for planning targets, ways, and magnitude of development funding,

- Community cooperation, this approach considers the needs for and on behalf of community groups, to be able to realize active cooperation in the community.

Negative perceptions, which are essential issues from the FSRU development plan and land pipeline deployments that can lead to a dispute in the social environment, include 1. Loss of land/assets and community concerns originating from land acquisition. To minimize these negative perceptions, the recommended forms of social management are: Establish a community complaint center to be used by the community as a means of providing input regarding land acquisition and deliberation; and form a community complaint center to be used by the community as a means of giving input regarding land acquisition and notification and permission requests to muspika related to survey plans and dissemination of activities by bringing assignment letters from relevant agencies; 2. Environmental pollution originating from construction activities. 3. Pipeline maintenance and emergency response to gas pipe leakage/damage. To minimize pollution, it is necessary to manage social approaches, institutional and technological approaches.

\section{Bibliography}

Arifin, Z. at al. (2019). Studi AMDAL Pembangunan Penyimpanan LNG Terapung dan Fasilitas Pendukungnya.

Erna, R., Sunsun, S., \& Dyah, R. P. (2011). Perencanaan dan Pengembangan Wilayah. Bandung: : Crestpent and Yayasan Pustaka Obor Indonesia.

G. Pruitt, D., \& Z. Rubin, J. (2011). Teori Konflik Sosial. Yogyakarta: Pustaka Pelajar.

Murad, R. (2019). Penyelesaian Sengketa Hukum Atas Tanah. Alumni.

Presidential Decree No.59 Year 2017 about National Development Goals (SDGs) for 2016 - 2030.

Rahman, A. at al. (2018). Feasibility Study Report of The Development Plant "Floating Storage Regasification 
Unit” (FSRU) Pasuruan. P.T Regas Energitama Infrastruktur.

Sahab, K., \& Sugihen. (1977). Perubahan Nilai-Nilai Sosial Budaya (Kajian Kasus Perubahan Fungsi Lahan Pertanian ke Non Pertanian pada Masyarakat) Bengkulu.

Saputra, R., \& Muhammad. (2017). Lumpur Lapindo 11 Tahun: Masalah Lingkungan dan Kesehatan Masih Mengancam Warga. Retrieved from https//www.voaindonesia.com/lumpur-lapindo-11-tahun-masalahlingkungan-dan-kesehatan-masih-ancam-warga/3875373.html

Sembiring, A. R. (2016). Faktor-Faktor yang Mempengaruhi Pengungkapan Tanggung Jawab Sosial. Accounting and Finance Journal, 18(2).

Susilowati, E., Moerad, S. K., \& Arifin, Z. (2018). PENGARUH EMIC VIEW TERHADAP PENETAPAN KELAYAKAN LINGKUNGAN RENCANA PEMBANGUNAN JAWA-BALI. Jurnal Sosial Humaniora, 11(1), 39. https://doi.org/10.12962/j24433527.v11i1.3735

Susilowati, E., \& Windiani, W. (2018). PENDEKATAN REKAYASA SOSIAL DALAM PENGELOLAAN SUMBERDAYA AIR (Studi Kasus Pengadaan Tanah Untuk Pembangunan Bendungan Semantok Di Kabupaten Nganjuk-Jawa Timur). IPTEK Journal of Proceedings Series, (5), 1. https://doi.org/10.12962/j23546026.y2018i5.4415

Wahyono. (2005). Pemberian Izin Pemanfaatan Tanah Sebagai Upaya Pengendalian Hukum. 